\title{
RESULTS OF OTOPLASTY BY SCORING ANTERIOR SURFACE OF AURICULAR CARTILAGE
}

\section{AUTHORS}

Gašić J. ${ }^{1}$, Jović R. ${ }^{2}$, Filipović M. ${ }^{3}$, Lemajić Komazec $S{ }^{2}$, Komazec Z. ${ }^{2}$, Božić B. ${ }^{2}$

${ }^{1}$ Medical Faculty Priština - Kosovska Mitrovica, ENT Clinic, Serbia

${ }^{2}$ Medical Faculty Novi Sad, University ENT Clinic, Serbia

${ }^{3}$ Medical Faculty Priština - Kosovska Mitrovica, Surgery Clinic - Department of Plastic Surgery, Serbia
KORESPONDENT

\section{JUGOSLAV GAŠIĆ}

Medicinski fakultet, Univerzitet u Prištini, Kosovska Mitrovica, Srbija

$\bowtie$ jugogasic@gmail.com

\section{SUMMARY}

A prominent ear, so called a protruding or "lop" ear, is the most common congenital deformity of the external ear. This deformity persists when the mastoid-helix angle (MHA) is higher than 30 degrees. It is relatively common among the population with the incidence of about $5 \%$. The aim of this study is to present surgical procedure and our results using otoplasty with scoring anterior surface of the auricular cartilage. To analyze objective and subjective surgical procedure effects. Between 2011 and 2014 we treated 28 patients. We found statistically high significance $\mathrm{p}<0.01$ in value mastoid-helix angle (MHA) preoperative and postoperative. In patients with bilateral otoplasty the difference between left and right MHAs after surgical procedure is less than 4 degrees. The difference of head-helix distance (HHD) preoperative and postoperative is statistically important with high significance $p<0.05$. Preoperative satisfaction by personal appearance was better after surgical procedure $p<0.05$. Complications occurred in 9 cases $(32.4 \%)$. Otoplasty by scoring anterior surface of auricular cartilage is safe procedure for correction of prominent ear with excellent results on patient satisfaction by personal appearance. Effect of reducing the MHA and HHD is long lasting.

Keywords: otoplasty, scoring, results

\section{INTRODUCTION}

A prominent ear, so called a protruding or "lop" ear, is the most common congenital deformity of the external ear [1]. This deformity persists when the mastoidhelix angle (MHA) is higher than 30 degrees [2,3]. It is relatively common among the population with the incidence of about $5 \%$. There are three main causes when this condition occurs alone or in combination, presence of an excessive conchal cartilage, immature antihelical fold, and abnormal attachment of the auricle to the side of the head [1]. This deformity can be seen within the first year of life and full expression is in early school age. There are numerous anthropometric studies showing that up to $90 \%$ of the auricular growth is already completed at an age of 11 to 12 years [4,5]. Prominent ear is not functional problem, it is morphological but it also may give rise to serious emotional problems in children and also in adults. Children with protruding ears are often exposed to substantial psychological pressure, such as being teased at school or in kindergarten. Numerous otoplasty techniques have been developed to optimize the appearance and position of the prominent ear. In general, the procedure is a combination of incision, scoring and suture techniques. Otoplasty with scoring of the anterior surface of the auricular cartilage is one of the most commonly used procedures $[1,5]$.

\section{THE AIM}

The aim of this study is to present surgical procedure and our results using otoplasty with scoring anterior surface of the auricular cartilage. To analyze objective and subjective surgical procedure effects.

\section{MATERIAL AND METHODS}

We induce local anesthesia with approximate $4 \mathrm{ml}$ Lidokain-Adrenalin $(80 \mathrm{mg}+0,05 \mathrm{mg})$ and perform app. 4 $\mathrm{cm}$ ellipsoid strip of posterior auricular skin excision. Posterior soft tissue undermining is performed to expose the cartilage. Cartilage is then incised from the superior antihelical crus to the tail of the future antihelix. We carefully detached skin from the cartilage in the anterior aspect. The anterior surface of the cartilage we scored with concentric and crosshatched cuts. This maneuver weakens the ear cartilage, which curves spontaneously. With three 4/0 Vycryl stitches we stabilize the newly reconstructed anthelix. Stitch knots have been placed into the rolled cartilage flap. The skins closed using non-absorbable 4/0 mattress stitches placed horizontally. The ears are dressed by stuffing of the triangular fossa, concha and scapha with cotton with octenidine-dihydrochloride solution. Dry gaze covers the cotton. An elastic bandage holds the dressing in place for 10 days, to be 
checked daily after surgery for 4 next days and then once in two days until the 10th day.

We analyzed the age, sex, mastoid-helix angle (MHA) pre and postoperative, head-helix distance (HHD), subjective satisfaction with the personal appearance pre and postoperative. Measurement of MHA was being done by protractor. Measuring three site of triangle is possible to calculate by protractor MHA. Measurement of HHD was being done by ruler. Patients fill in personal questionnaire about personal appearance satisfaction. Highest score is 5 and correlate with largest satisfaction. The lowest value is 1 and correlate with lowest satisfaction. All data are processed using SPSS statistical package.

\section{RESULTS}

Between 2011 and 2014 we treated 28 patients (22 females and 6 males). We performed a total of 52 procedures (24 bilateral and 4 unilateral). The patients were between 8 and 32 years old (mean value 19).

Mastoid-helix angle (MHA) was preoperative, between 43 degrees and 72 degrees (mean 61 degrees) and postoperative, between 15 and 21 degrees (mean 17 degrees). There is statistically high significance $p<0.01$ in value MHA preoperative and postoperative. In patients with bilateral otoplasty the difference between left and right MHAs after surgical procedure is less than 4 degrees.

There is no statistical significance between postoperative values of MHA between left and right ear $p>0.05$. Head-helix distance (HHD) was preoperative, between $27 \mathrm{~mm}$ and $39 \mathrm{~mm}$ (mean $32 \mathrm{~mm}$ ) and postoperative, between $9 \mathrm{~mm}$ and $15 \mathrm{~mm}$ (mean $12 \mathrm{~mm}$ ).

There is statistically high significance $p<0.05$ in value HHD preoperative and postoperative. Preoperative satisfaction by personal appearance was 1.38 (mean value) and postoperative mean value was 4,76 . There is statistical significance $p<0.05$ in personal satisfaction pre and postoperative. In 9 cases (32.4\%) we have complications.

The most frequently blisters occurs, in 9 operated ears $(17.3 \%)$, hematoma occurred in $5(9.6 \%)$ and in 1 (1.9\%) case bleeding occurred during the operation.

Fiugure 1. Hematoma (A) 3rd postoperative day, (B) 8th postoperative day
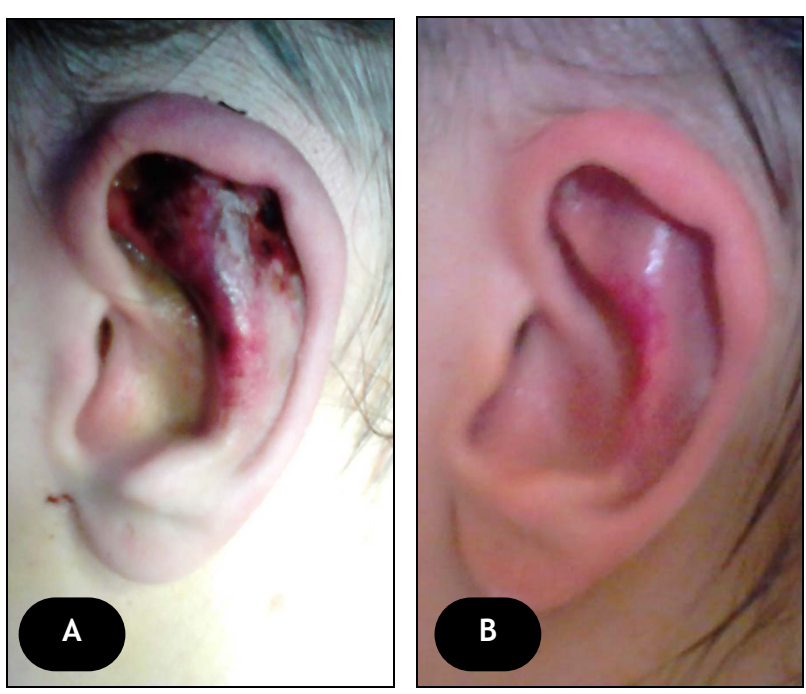

Figure 2. (A) Front view preoperative, (B) Back view preoperative, (C) Front view postoperative, (D) Back view postoperative
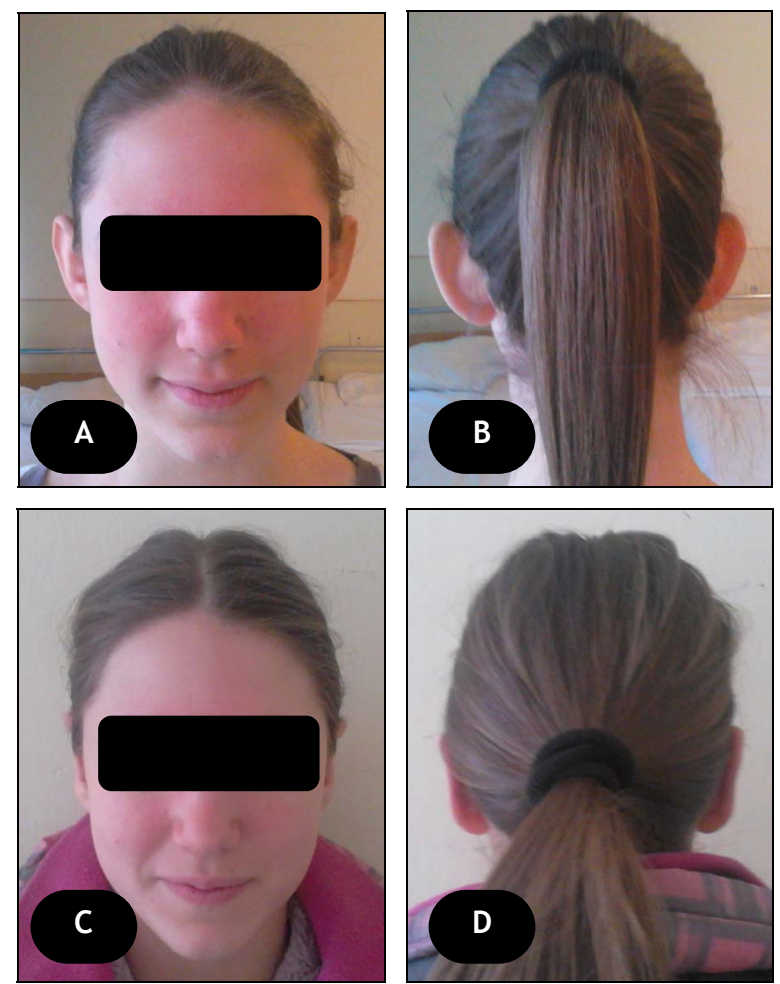

\section{DISCUSION}

The external ear is a complex structure with great variation between individuals and even between the two sides of the same individual [1]. The fine contour of the ear is determined by the form and shaping of the elastic auricular cartilage, which is covered by a skin with fine pores. Over 200 different procedures have been described and proven successful to provide satisfaction to the patient $[6,7]$. The standard methods include the suture technique according to Mustarde, the incision-suture technique according to Converse, and the incisionscoring technique according to Stenstrom, Chongchet and Crikelair. We modified the Chongchet otoplasty technique and focus on creating a new antihelical fold and reducing the mastoid-helix angle. By this technique we successfully decrease MHA and HHD with slight deviation values of the MHA between ears of the same patient. Apart from reducing the mastoid-helix angle to $15-20^{\circ}$, emphasis on the antihelical fold and smooth rim of the helix without interruption of the contour are desirable outcomes of this operation $[5,8,9]$. This procedure provided safe results in postoperative period during 6 months. We do not have any need for reoperation. Postoperative satisfaction by personal appearance is significantly better. Low self-esteem, general lack of self-confidence, and social isolation are amongst the reason why parents of affected children or affected adults decide for this procedure [7]. The negative side of this procedure is complications. We noticed that complications are lesser during the years of experience and the most frequent are epidermal blisters and hematoma. The incidence of blisters can be decreased by usage of cotton instead of gaze. For postop- 
erative care after otoplasty, packing with cotton or straps soaked with octenidine-dihydrochloride solution or antibiotic agents have proven to be effective. With these measures, the contour of the newly formed auricle is stabilized and an infection is prevented $[10,11,12]$.

\section{CONCLUSION}

Otoplasty by scoring anterior surface of auricular cartilage is safe procedure for correction of prominent ear with excellent results on patient satisfaction by per- sonal appearance. Effect of reducing the MHA and HHD is long lasting. The negative side of this technique, occurrence of complications can be reduced by improving postoperative care.

\section{REFERENCES}

1. Sivrioglu N., Irkoren S., Aksoy B., Copcu E. (2012) Chong-Chet Anterior Scoring Technique for the Correction of Prominent Ears: Results in 30 Patients. Modern Plastic Surgery;2:39-42.

2. Farkas LG. (1990) Anthropometry of the normal and defective ear. Clin Plast Surg;17:213-8.

3. Siegert R., Krappen S., Kaesemann L., Weerda H. (1998) Computer assisted anthropometry of the auricule. Face;6:1-6

4. Kalcioglu MT, Toplu Y, Ozturan O, Yakinci C, (2006) Anthropometric growth study of auricle of healthy preterm and term newborns. Int J Pediatr Otorhinolaryngol 70:121-7

5. Naumann A.(2007) Otoplasty - techniques, characteristics and risks. GMS Current Topics in Otorhinolaryngology - Head and Neck Surgery, Vol 6:1-14.

6. Johnson P.E. (1994) Otoplasty: Shaping the Anthelix. Aesthetic Plastic Surgery. Vol.18:No.1:71-77.

7. Schwentner I, Schmutzhard J, Deibl M, Sprinzl GM (2006) Health-related quality of life outcame of adult patients after otoplasty. J Craniofac Surg 17:629-35.

8. Peker F, Celikoz B. (2002) Otoplasty: Anterior Scoring and Posterior Rolling Techniques in Adults. Aesthetic Plastic Surgery. Vol.26. No.4:267-273.

9. Chongchet V. (1963) A method of antihelix reconstruction. Br J Plast Surg 16:268.

10. Bhati A.Z, Ijaz M. (2013) Sutureless Otoplasty: Anterior Scoring of the Antihelical Fold. Advanced Cosmetic Otoplasty 267-270.

11. Rubinho C, Farace F, Figus A, Masia D.R, (2005) Anterior Scoring of the Upper Helical Cartilage as a Refinement in Aesthetic Otoplasty. Aesthetic Plastic Surgery. Vol.29:No.2:88-93.

12. Yugueros, P, Friedland, JA (2001) Otoplasty: The experience of 100 consecutive patients. Plast Reconstr Surg 108:1045-51

\section{SRPSKI}

\section{REZULTATI OTOPLASTIKE SKARIFIKACIJOM PREDNJE STRANE AURIKULARNE HRSKAVICE}

Gašić J. ${ }^{1}$, Jović R. ${ }^{2}$, Filipović M. ${ }^{3}$, Lemajić Komazec S. ${ }^{2}$, Komazec Z. ${ }^{2}$, Božić B. ${ }^{2}$

${ }^{1}$ Medicinski fakultet Priština, Klinika za ORL, Kosovska Mitrovica, Srbija

${ }^{2}$ Medicalfakultet Novi Sad, Srbija

${ }^{3}$ Medical fakultet Priština, Kosovska Mitrovica, Plastična i rekonstruktivna hirurgija, Srbija

\section{SAŽETAK}

Odstojeće uši ili u narodu „klempavost“ je najčešća kongenitalna deformacija spoljašnjeg uva. Deformitet postoji kada je mastoidheliksni ugao (MHA) veći od 30 stepeni. Deformacija je relativno česta u populaciji sa incidencom od $5 \%$. Cilj ovog rada je prezentacija hirurške procedure i naših rezulatata korišćenjem otoplastike sa skarifikacijom prednje strane aurikularne hrskavice. Analiza objektivnih i subjektivnih efekata nakon hirurške procedure. U periodu od 2011. do 2014. godine operisano je 28 pacijenata. Našli smo statistički značajnu razliku $p<0.01$ u preoperativnim i postoperativnim vrednostima mastoid-heliks ugla (MHA). Kod pacijenata sa bilateralnom otoplastikom razlika između levog i desnog MHA nakon hirurške procedure je manja od 4 stepena. Razlika preoperativnih i postoperativnih head-helix distance $(H H D)$ je statistički značajna $p<0.05$. Zadovoljstvo ličnim izgledom je bolje nakon hirurpke procedure $p<0.05$. Komplikacije su se javile u 9 slučajeva (32.4\%). Otoplastika sa skarifikacijom prednje strae aurikularne hrskavice je bezbedna procedura za korekciju odstojećih ušiju sa odličnim rezultatima u zadovoljstvu ličnim izgledom. Efekti redukcije MHA i HHD su dugotrajni.

Ključne reči: otoplastika, skarifikacija, rezultati. 